\title{
Quality Management in Higher Education; Challenges of Private Universities in Albania
}

\author{
Skender Bruçaj
}

Educational Sciences, Beder University,

\begin{abstract}
Higher education is considered as one of the main socio-economic development factors of the society. Quality assurance in higher education shall be one of the main priorities of the government and civil society. Expectations for a better performance in the quality of teaching, scientific research and other similar activities, obliges the university managers and administrators to review their strategy. For this reason, the demand for quality in higher education is increasing. After assessing the current state of the private educational institutions in Albania in terms of quality and of identifying the existing issues, there will be provided some recommendations and suggestions for improvement in relation to the future challenges. For this reason, in the theoretical framework of references from literature assessment, a specific total quality management framework (TQM) will be developed.
\end{abstract}

Keywords: Higher Education, Quality, SWOT, TQM, Private Universities

\section{Introduction}

As society is going towards globalization, the competition is getting stiffer. Many business institutions are not only trying to fulfill the needs of the clients but also to go the extra mile. This can be achieved only by reducing costs, continuous improvement in standards and quality of service. Business institutions, in order to increase their profits and survive the market competition, have the necessity to increase the quality of products and services. Lately, quality has taken the main spot in the agendas of different companies and institutions, but despite this, many people do not have a clear idea about the concept of quality, and especially in services, the concept of quality takes an enigmatic shape.

In our daily life, in most cases, we take quality for granted and we encounter difficulties in defining it as a concept. Although, for some of us, quality can be a subjective term and we can have different definitions for it, we are all aware and recognize quality when we experience it. Crosby (1979) defines quality as "conformance to requirements and standards", whereas Juran and Gryna (1980) define it as "fitness for use". Deming (1986) defines quality as "predictable degree of conformity", "security with a low cost" and "conformity to the market". Now many companies find out that the old definition of quality, thus "complying with standards", is very narrow and, according to these companies, generating profit and exceeding client's expectations are placed in the centre of quality. To achieve quality, many business institutions and companies follow systems of quality management, such as the international standards ISO 9000:2000.

Higher Education in the Republic of Albania, as everywhere in the world, is considered as a service and a benefit to the society. The issue of expansion of Higher Education in our country and its sociological effects shall anticipate and adapt to changes in the labor market and in its socio-economic development.

The issue of quality assurance in Higher Education, apart from other things, has to also do with adaptability, more advanced models, practices and concepts followed in the world, related to university system. The post-communist era in Albania and the opening of the country towards the West, created the premises and equal opportunities for all student youth to begin their Higher Education studies not only within the country but also abroad. Attending different universities abroad, made for this new generation to understand not only new and innovative knowledge and delivery of science but also all shaping, mentality and carrying forward a new philosophy in education for the generations to follow. Apart from public universities, the first non-public Higher Education Institutions started to emerge, which would bring higher academic freedom, attracting the best experts in the market for all subjects, and bringing more capable academic staff, who, based on a better organized 
system, gave their contribution in increasing the number of excellent students and the quality and standard of teaching and learning. (Laze, 2011)

\section{Presenting the issue}

Recently, there is identified a worldwide interest in quality assurance standards in higher education. Also, in Albania's scenario, it has become a necessity to develop and follow a clear strategy in implementing quality standards in the area of higher education. In Albania's conditions, the issue of securing and continuous improvement of quality standards in the private sector of higher education gets an even higher importance. This is because of the fact that owing to certain dynamics that have accompanied this sector in the 2000s and onwards, there was a 'not-so-positive' perception towards them, in comparison to the public institutions of higher education. To reach the standards of developed countries in the area of higher education, Albanian universities have to increase certain standards that are related to teaching, improving the procedures of quality assurance and in the same time, it must be worked towards developing and to progress this system based on internal assessments of quality managers or external accrediting teams. Quality assurance in higher education cannot only be a cause monitored from public institutions. Raising awareness to civil society and stakeholders comes as a necessity for this process to be successful in itself. It is very important for the public and non-public universities to clearly prove that are seriously considering these processes, being ready to define a clear path on implementing quality standards and being transparent in publishing results of this process.

\section{Aim of this Study}

To this day, the Higher Education in Albania hasn't reached the international standards, despite the efforts of responsible institutions of higher education, whether the relevant Ministry, or even the responsible agencies or boards, but also Institutions of Higher Education ( $\mathrm{HE}$ ), in the framework of improving quality in this sector. The Albanian legislation obliges IHEs to undergo accreditation processes in institutional level and in study programs level. But, despite this, the result has been somewhat disappointing for the institutions of higher education that operate in the private sector, because not all IHEs that exert activity are involved in this process. Up to 2015, there was almost no public institution that had undergone processes of external assessments, regarding quality issues. Meanwhile, on the other hand, almost all private IHEs had undergone auditing processes in institutional level but also in the studying program level. All vagueness and continuous amendments in the law of higher education have negatively impacted the academic world, becoming a barrier in improving the standards of higher education.

\section{The Importance of this Study}

Total Quality Management, being that has had a wide expansion in the industry and business world, is an important concept to be considered and analyzed in the academic sphere. This study will serve as a stimulus for different researchers in relation to quality and will also come in hand to experts of education being that is one of the first studies in the area of TQM for the private Higher Education. This work aims to provide a modest contribution to understand the dynamics of quality management in higher education and challenges of private universities in securing and continuous improvement of quality in private higher education in Albania.

\section{Research questions:}

Can the principles of total quality management be successfully applied in the area of higher education in the Albanian private IHEs?

How effective is the internal self-assessment based on TQM of a higher education institution in support of continuous improvement of quality?

What are the barriers that are faced in implementing IHEs in the private higher education?

Are the so-called quality systems, i.e. quality systems defined from group of standards ISO 9000, useful to be implemented in the higher education? 


\section{Quality of Higher Education}

Different business institutions are continuously seeking, not only to improve the general organizational performance in order to be more effective and competitive in the market, but in the same time, have to get there in the shortest time possible. This, undoubtedly, cannot be achieved without a clear vision, without a strategic plan and without aiming the right quality in products and services, as an important determinative factor for the success of companies.

Lately, expansion of Higher Education and internationalization of its institutions has significantly impacted in raising awareness of main stakeholders of this area on the importance and role that quality has in achieving success in the market of Higher Education institutions where the competition is increasing day by day. Defining quality in the service area is not easy, but this becomes even harder when it comes to Higher Education. Despite many different quality theories and models have tried to define and measure quality in Higher Education, the quality in this educational level receives an enigmatic and subjective shape, thus getting into a universal definition of quality in higher education is almost impossible.

Harvey refers to the notion of quality in higher education as a relative concept, being supported in the reason that defining quality is relative and different from one individual to the other, depending on circumstances and expectations, where quality means different things in different moments (L. a. G. Harvey, D., 1993). Numerous stakeholders in Higher Education including: students, lecturers, administrative personnel, employers, etc. issue totally different nuances to the notion of quality based on the experiences that they have, circumstances they find themselves into, perceptions that they have in relation to the possible needs and wants. Institutions of Higher Education, like all other business organizations, are involved in the production process but in the contrary of proper business organizations, the quality of production cannot be defined based only on some components. A more accurate definition of quality can be achieved if we were to carefully analyze all components of quality, as in design phase, drafting phase but also during other processes.

A way to clearly see the quality issue in Higher Education is focusing in all possible quality component elements. Particularly, the quality in drafting in higher education has to do with outputs (results) on how a planned program to fulfill student's needs, can be considered and quality in process is more related with implementing academic programs, planning, assessments and other factors that impact the program. (Chaffee, 1992)

Some of the components of Higher Education, which are considered important from the quality assessment agencies, are found as follows. (ENQA, 2015)

Physical infrastructure (buildings, sports complexes or premises) of universities;

Academic infrastructure (labs, bookshops, documentations, communication and informatics);

Contemporary curriculum and in coherence with the market needs;

Exams and evaluation system;

System of enabling and developing academic/administrative

personnel; Scientific-research work and publications;

Institutional development plan (short-term and long-term strategic planning);

Relationship in the trinomial university-industry-society.

In absolute terms, quality does not mean the best. Conceptual diversity of the quality notion is based on the client's perception, in other words, is based on the trust scale that client have in fulfilling their needs and requests. But beside this, the quality notion is multidimensional, that's why we cannot have a definition of quality focusing only in one of its characteristics. (Deming, 1986)

Quality in education means the level of acquiring knowledge and habits as a result of learning. In the education process, what remains in the end of it, comes as a result of learning, that is evidenced with the increasing of theoretical formation and abilities acquired from students that aid in facilitating their integration in the labor market. (Hernon, 2002)

One of the difficulties faced from the institutions of Higher Education is the fact that they must have clear policies in defining quality standards, in order for them to be conscious on their responsibilities for the process of quality assurance and management in Higher Education. 
Table 1 - Summary of SWOT analysis results of private IHEs in Albania (Brucaj, 2015)

\section{Challenges of private education institutions in Albania}

\begin{tabular}{|l|l|}
\hline $\begin{array}{l}\text { Strengths (S) } \\
\begin{array}{l}\text { Well educated academic team inside and outside } \\
\text { of the country. }\end{array}\end{array}$ & $\begin{array}{l}\text { Weaknesses (W) } \\
\text { Insufficient processed management of quality } \\
\text { assurance. Insufficient provisions of faculties with } \\
\text { theoretical and practical curriculum. }\end{array}$ \\
$\begin{array}{l}\text { worldwide with the contents of European } \\
\text { universities. }\end{array}$ & $\begin{array}{l}\text { Insufficient foreign curriculum for teaching. } \\
\text { Low motivation of lecturers, low wages and }\end{array}$ \\
Presence of information management systems. & $\begin{array}{l}\text { inadequate work conditions. } \\
\text { Low motivation of students, because of lack of } \\
\text { employment opportunities. }\end{array}$ \\
& $\begin{array}{l}\text { Very poor financing. } \\
\text { Weak scientific collaboration of universities and }\end{array}$ \\
& $\begin{array}{l}\text { faculties with European universities. } \\
\text { Relatively new }\end{array}$ \\
\hline $\begin{array}{l}\text { Opportunities (0) } \\
\text { Albania's integration process in the EU, attending } \\
\text { different projects in quality assurance and } \\
\text { developing study programs. }\end{array}$ & $\begin{array}{l}\text { Threats (T) } \\
\text { Material crises in the country, in the } \\
\text { New institutions, option of implementing a } \\
\text { functional and effective system, since the } \\
\text { beginning. }\end{array}$ \\
\hline
\end{tabular}

Higher education in Albania has not reached international standards yet, even though in the last years there have been efforts to improve public standards in terms of quality in higher education and the monitoring process from internal and external accrediting bodies. Moreover, there has been an attempt to rank universities but the result has been somewhat disappointing, for the fact that in this process there weren't included all institutions of higher education in the country. Ambiguities and continuous changes in the law on higher education have had a negative impact in the academic world, becoming a barrier in improving standards of higher education. The need for an effective system and the lack of an advanced and designed methodology to secure quality in higher education, especially in the non-public one, has made it more difficult to achieve quality standards in the higher education (Tarifa 2009).

The events that occurred after the 90 s, as in every other sector, even in education, brought up the need to reorganize higher education, steps that had to be followed to pass in a higher level in order to adapt student's capabilities to the new development conditions of the country. Higher education passed into several phases, with its ups and downs, and in coherence with the dynamics of economic development of the country and the increased demand of youth to follow higher education.

In 2003, Albania officially becomes part of Bologna process. This year is the systematic initiation of adapting the curriculum of higher education by being based on this system, with the ECTS concept and its implementation. This is the crucial process in formatting higher education, by adapting it with European one, which still remains unfinished, especially in the aspect of harmonizing curriculums, based on university cycles and profiles, nationally and internationally. Starting from 2002, the first private IHEs are licensed, which were mainly profiled and up to 2005 there were counted 5 such IHEs.

During this period, the main problem of these IHEs was the lack of a full legal framework, that covered everything and that issued full standards in the process of allowing to establish and explaining the method of functioning of these private institutions. This can be considered as the greatest challenge encountered from these institutions during their functioning 
in this period. Afterwards, during 2005-2009, there were established 34 new private institutions and one public institution, whereas during 2009-2013, there were established two public IHEs and 10 private ones (APAAL. 2015).

The issue that was encountered after the establishment of a high number of private IHEs, was not only their high number, but the lack of monitoring and impunity for different breaches, where the abuse started in functioning within standards for these IHEs and the distortion of the higher education market, up to the issuance of diplomas without sometimes fulfilling the most minimal conditions of the learning process.

2014 marked a strong and in the same time difficult turn. Reassessing the legality of private higher education institution became a necessity and resulted in closing 15 private $\mathrm{IHEs}$, which were stripped out from the right of educational activity by suspending the given licenses. Even though there was a chaotic situation, within a short time, this step brought selfcontrol not only in the private higher education system, but also in the public one and a disciplining process initiated in further expansion, even though without a clear plan, but nevertheless slower and more controlled when establishing new institutions.

This whole process was followed in the framework of the reform in higher education undertaken from government Rama 1 (2013-2017). The main components of this reform were:

Legality control for 2013-2014, which was finalized by closing or suspending a number of IHEs.

Preparation of a law for higher education, which was passed in September 2015.

Accreditation of all IHEs from ASCAL, in collaboration with one of the best agencies in Europe, that of QAA (Quality Assurance Agency) from the United Kingdom.

One of the challenges of private higher education in Albania is to strengthen the role of universities in scientific research, turning into entrepreneurial universities focused on innovation, away from a business model that stands only for profiting financially. According to Ministry of Education and Science (MES), the main challenges in the area of higher education are:

i) in adapting curriculums with the same pace as the social, economic and market changes; ii) developing a continuous monitoring functional system to guarantee quality assurance; iii) accreditation of programs, and rigorously following the implementation of quality standards from the universities; iv) drafting curriculums development policies with the aim to orientate the youth as best as possible towards the labor market (MES, Final Report 2014).

But what remains to be the main challenges of private higher education in Albania and for the institutions that represent this area? We are ranking these challenges as follows, by issuing a short summary, and here and there, issuing possible proposals to overcome them.

\subsection{Image of private universities: between prejudice and reality}

Private universities in Albania, despite being in greater numbers, in most of the cases continue to be chosen after public universities. This is clearly understood by taking into consideration the high number of students that apply in programs of public universities, and the number of those that register in there. Although many private universities provide better infrastructure or conditions, being that they are privately funded, the continuation of studies in these institutions seems to continue to create a wince to the parents, but also to the young people. But what makes them to be the most wanted of all; quality, lower prices or the diploma in the end of the studies?

In the selection process of a university, the individual student factors have an impact. From a quick analysis it is noticed that the financial side is a very important element that impacts the selection of public universities to study, but the created image, related to private IHEs, after the accreditation from the British Agency (QAA) and quality criteria verifications, based on European standards, it also seems to have a great impact in the selection process from the youth to continue their higher studies and gives them assurance in selection. Another factor is the diploma; will it assist the student to integrate in facing competition in challenges of regional and global labor market?

Decision-making in relation to registering in private universities always seems to be a long process that requires answers for many questions, as compared to the process of selecting a public university. Although, during recent years, there are stakeholders of private higher education, who have contributed in forming successful models in private higher education. It seems that achieving a stable and mature image will require more time. 


\subsection{An incomplete, unstable legal framework and mixing different models}

Private higher education in Albania, as in many aspects of the private sector, was established from point zero, starting almost one decade later than the fall of the communist system. The main issue of such processes always starts in constructing an appropriate and functional legal framework, which shall also be dynamic with the development stages of that sector.

The first challenge in these cases is drafting and implementing a law that must be implementable and this, when it comes to Albania, has resulted to always be an issue and very difficult to be achieved, because laws for higher education (1999, 2007 and 2015) were drafted with a different approach and using different models. This brought the disorientation, in general, of the higher education system and in particular, in the private higher education (MASH 2015).

Without fully implementing the law and bylaws, the process of drafting a new law initiated. In the dynamics of higher education in Albania, having a new law was not the main issue, but changing models brought a higher difficulty. These difficulties were related starting from the financial management side up to the recruitment and appointing of officials. This brought confusion in this sector and to stakeholders that have started projects of establishing IHEs based on previous conditions.

\subsection{Capacities and development of human resources}

A fast increase of IHEs in Albania, in the managerial aspect, brought another difficulty that was related with insufficient experienced human resources in this sector. Consequently, this impacted in the healthy and normal functioning of these institutions. As managers of academic and administrative structures, there were many occasions where it was impossible to find people that had the relevant qualification, being obliged to cover that vacancy with people that were nearer to that position. The incompetency in resolving many new issues that were not encountered before slowed the process and, in many cases, they were misinterpreted ( CHE 2011).

Human resources capacities problems were also related to the unstableness in academic and in administrative staffs, where in many institutions there was encountered frequent changes of people in managerial, academic or administrative levels. These changes had a direct impact in healthy functioning of these institutions, creating confusion and instability in their progress.

\subsection{Admission system and method of students in university, an insurmountable challenge}

Admission of students in universities is one of the most important and critical parts for an IHE, in order to have a proper functioning and to successfully achieve its mission. In many cases, up to 2016, the admission of students was centralized for public universities, whereas the private ones accepted applications through submission of files, assessing based on the rules and conditions defined from the relevant institutions. The issues that were encountered from this method of admission, had to do more with the vacuum that was created in monitoring possible breaches that could be made in the private higher education system, where there were cases when deadlines or other necessary conditions were not applied for a proper educational process. The new law on higher education changed the admission method, conditions and criteria of being accepted in university and the new admission method brought up some difficulties and new issues that created confusion for the IHEs but also for the high school graduates that were applying to enter universities.

Currently, the admission system, although has disciplined many issues and previous deficiencies, remains not totally finalized, and might require a long time to be consolidated.

\subsection{Demographic developments and the decrease in the number of students}

Demographic developments based on the decreasing number of populations can be undoubtedly considered as one of the main challenges of education in general, including all levels. For the private higher education institutions in Albania, the most serious problem remains the fulfillment of quotas in an acceptable level. This comes for several reasons. One of the reasons is the lack of a periodic report, related to the analysis of market needs, and opening of programs without a sufficient planning in place.

Apart from this, another reason is related to the demographic development in the country. Based on the statistics, the number of students in the high school education is decreasing; the demographic graph has a significant decrease of high 
school graduates and the ones coming after them. This is because of the decrease in birth rate, and the significant number of people leaving the country to go abroad, mainly in the EU. In the latest years, the number of students registered in these programs has been low. As a consequence, many programs, but also many private IHEs, not only risk their existence but directly harm the quality of teaching. This, in the near future, will have a considerable impact in registrations in higher education. For private IHEs to guarantee their progress, one of the things that they might do is to avoid overlaps of academic offers and to adapt their programs with market demand (Minxhozi 2013).

\subsection{Financing and financial stability}

In Albania, the level of financing higher education is lower than the other European countries, including the regional ones. Public and private IHEs, have limited possibilities to generate alternative income, in support of increasing quality in teaching and scientific research. Although some taxes are not applied in education, such as value added tax, private institutions remain between the pressure to add revenues from students and not having other financial resources or donators in supporting teaching process and especially research process.

Some gaps and opportunities found in law no. 80/2015 "On Higher Education and Scientific Research in Higher Education Institutions of the Republic of Albania", where private IHEs can benefit from, seems like it requires time to be achieved in completing bylaws but also from the low financing level in education. This will directly impact in the unhealthy functioning of a significant number of IHEs and maybe in closing/bankrupting some of them.

\subsection{Scientific research in private IHEs: mission impossible}

In completely fulfilling the mission, IHEs must continuously invest to improve infrastructure and encourage scientific research. In a thorough analysis, it is observed that private IHEs have a significantly higher investment in infrastructural aspects, such as labs, bookshops or at minimum, classes and auditors with better standards in delivering the teaching process. But the same thing cannot be said in relation with the financing that these institutions give for the scientific researches. Although a limited number of universities defines a budget, even though is very limited, for scientific research, most of private universities are in a very low level. Not only internal financing, but also external ones, especially funds for projects from the EU, are also very low, as compared to public IHEs, and this is mainly because of the insufficient human resources that they have. Nevertheless, some private universities are moving rapidly towards increasing financing of research projects, by collaborating with domestic and foreign partners, in the framework of EU policies for higher education, research and innovation. This is a positive indicator that this situation can be different in a relatively short period of time.

\section{Quality framework}

Many universities have internal policies to ensure quality of service that they provide based on the academic experiences during the teaching process, social engagement, scientific researches, etc. Efforts in offering a qualitative higher education is concentrated in quality standards, in the requests of auditing commissions to draft programs and classes, and in comments based on internal and external stakeholders that aim to increase the general institutional performance. One of the main challenges of universities in Albania, as compared to their regional counterparts, is that they are relatively small universities and don't have a strong institutional culture and in the same time, don't have a large economic support, but they have a wide range of academic programs with limited resources. Therefore, it would be the right thing to do in specializing small private universities in specific areas. This approach would enable for these universities to be more competitive in the labor market.

One of the main challenges of non-public higher education institutions is the increase of access of Albanian youth in selecting education in non-public higher education IHEs and improving its standards and quality.

In other words, we can say that total quality management in higher education is the all inclusive managerial treatment for IHEs that is focused on continuous improvement of quality, enabling inclusion for all university's staff, students and stakeholders, aiming to exceed client's satisfaction and achieving the maximal performance of the university. To successfully implement these concepts, a total quality management framework shall be formed and a direct engagement of higher university officials that have the major responsibility in successfully implementing quality standards. 


\section{Quality management framework}

Quality framework, suggested methodology on total quality management in higher education doesn't dictate the abandonment of successful institutional cultures in relation to quality management, but offers an extra possibility to follow and to implement which in turn, contributes to increase quality standards and the performance of the university.

Establishing a system to assess teaching quality, by defining the teaching quality measuring indicators, would be an important step that impacts the increase of quality in higher education.

Table 2. Quality management framework in higher education

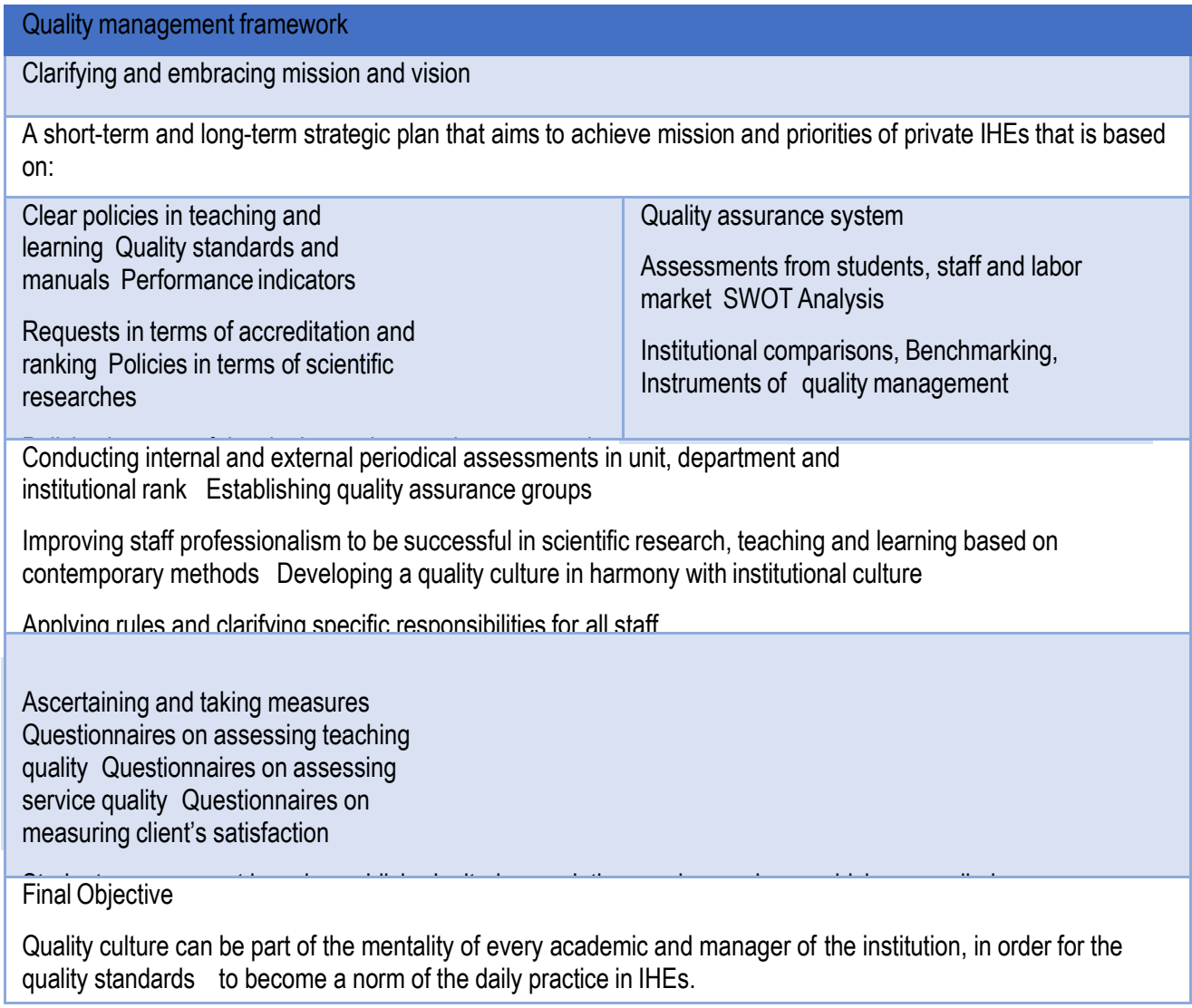

In conclusion

In conclusion we can state that quality of higher education, despite being difficult to define, is mainly a result of interaction between academic staff, students and the university's academic environment. The process of quality assurance and management must guarantee a learning environment where the programs content, learning opportunities and academic instruments are in accordance with the final objective of the university.

Higher Education Institutions in Albania, as compared with their regional counterparts, are relatively small and without a long institutional culture, that offer a wide range of academic programs with limited resources. Therefore, it would be appropriate in specializing small private universities in specific areas, which would enable these universities to be much more competitive in the labor market.

Moreover, Albanian private universities have to increase the quality of teaching, improve the procedures of quality assurance and in the same time, it must be worked upon developing and to progress this system based on internal 
assessments of quality managers or external accrediting bodies. Achieving quality and quality assurance in higher education cannot only be a matter monitored from state institutions. Raising awareness of civil organizations and stakeholders is a necessity for the success of this process in itself. It is very important for the private universities to clearly demonstrate that they are taking the processes of implementing quality standards with seriousness, being ready to define a clear path to follow relating to a transparent, accessible and clear for the public opinion set of standards, procedures and guidelines to achieve quality assurance and management in higher education.

\section{Biography}

[1] APAAL. (2015, 10 4). Institucionet jo publike te arsimit te larte. Accesed http://www.aaal.edu.al/sq/

[2] Brucaj, S. (2015). Using SWOT analysis to understand the institutional challenges in higher education system: a comparative study between albanian private universities. International conference on quality in higher education (f. 547). Sakarya: ICQH2015.

[3] Crosby, (1979). Quality is free. New York: McGraw - Hill.

[4] Juran, J.M. and Gryna, F.M. (1988) Juran's Quality Control Handbook. 4th Edition, McGraw-Hill, New York Deming, W. E. (1986). Out of the crisis. Cambridge MA: MIT.

[5] Hernon, P. (2002). Quality: new directions in the research. . Journal of Academic Liberianship, 28(4).

[6] ISO. (2001). Quality management systems. QMS. Guidance for Performance Improvement. Standard Publishing House.

[7] Harvey, L. \& Green., D. (1993). Defining quality. Assessment and Evaluation in Higher Education:. An International Journal, 18(1).

[8] Chaffee, E. E. (1992). Quality: Transforming Postsecondary Education. Washington, D.C: The GeorgeWashington University.

[9] ENQA. (2015). The Standards and guidelines for quality assurance. Accesed http://www.enqa.eu/index.php/home/esg/

[10] Tarifa, F. (2012). Dija, universiteti dhe demokracia. Tirane. Tirane: Ombra GVG.

[11] Minxhozi, L. (2013). Universiteti për zhvillimin origjina,modelet dhe impakti në shoqëri. Tirane: UET Press. CHE. (2011, 7 11). Development of ranking in Albania. Gjetur në https:/www.che.de/downloads/Ranking_Albania_Final_report_1307.pdf

[12] MASH. (2015). STANDARDET SHTETËRORE TË CILËSISË. Tirane: Republika e Shqipërisë, Ministria e Arsimit dhe Shkencës. 